\title{
Opposite effects of feeding a vitamin A-deficient diet and retinoic acid treatment on brown adipose tissue uncoupling protein 1 (UCP1), UCP2 and leptin expression
}

\author{
M L Bonet ${ }^{1}$, J Oliver ${ }^{1,2}$, C Picó ${ }^{1}$, F Felipe ${ }^{1}$, J Ribot $^{1}$, S Cinti $^{2}$ \\ and A Palou ${ }^{1}$ \\ ${ }^{1}$ Laboratori de Biologia Molecular, Nutrició i Biotecnologia, Departamento Biologia Fonamental i Ciències de la Salut, Universitat de les Illes Balears, \\ Crta. Valldemossa Km 7.5, 07071 Palma de Mallorca, Spain \\ ${ }^{2}$ Istituto di Morfologia Umana Normale, Facoltà di Medicina e Chirugia, Universita degli studi di Ancona, Via Tronto 10/A, 60020 Ancona, Italy \\ (Requests for offprints should be addressed to A Palou; Email: dbfapo0@ps.uib.es)
}

\begin{abstract}
The relationship between interscapular brown adipose tissue (IBAT) thermogenic potential and vitamin A status was investigated by studying the effects of feeding a vitamin A-deficient diet and all-trans retinoic acid (tRA) treatment on body weight and IBAT parameters in mice. Feeding a vitamin A-deficient diet tended to trigger opposite effects to those of tRA treatment, namely
\end{abstract}

increased body weight, IBAT weight, adiposity and leptin mRNA expression, and reduced IBAT thermogenic potential in terms of uncoupling protein 1 (UCP1) mRNA and UCP2 mRNA expression. The results emphasize the importance of retinoids as physiological regulators of brown adipose tissue.

Journal of Endocrinology (2000) 166, 511-517

\section{Introduction}

Brown adipose tissue (BAT) thermogenesis is a chapter of energy expenditure of critical importance in overall energy balance, at least in rodents, in which the tissue is particularly abundant (for reviews see Himms-Hagen 1990, Susulic \& Lowell 1995). It largely depends on the activity of the uncoupling protein 1 (UCP1), a brown adipocytespecific inner mitochondrial membrane protein that allows the dissipation as heat of the proton gradient generated by the respiratory chain during nutrient oxidation (for review see Palou et al. 1998). Other putative, UCP1-like, uncoupling proteins have been identified, namely UCP2 and UCP3 (Boss et al. 1997, Fleury et al. 1997, Gimeno et al. 1997, Vidal-Puig et al. 1997); these proteins are expressed in BAT as well as in other tissues from man and rodents, and their relative contribution to both adaptive thermogenesis and basal metabolic rate is not yet well defined.

BAT thermogenesis is highly regulated. Norepinephrine released from sympathetic terminals to BAT has a mainly regulatory role, triggering UCP1 activation, UCP1 synthesis, mitochondriogenesis and the proliferation of brown adipocytes (for review see Cannon et al. 1996). In addition, we and others have identified retinoic acid (RA), the hormonal form of vitamin $\mathrm{A}$, as a positive regulator of UCP1 gene expression, both in brown adipocytes in culture (Cassard-Doulcier et al. 1994,
Álvarez et al. 1995, Puigserver et al. 1996) and in intact mice (Puigserver et al. 1996). The effect of RA appears to be mediated by heterodimers of RA receptor and retinoid $\mathrm{X}$ receptor that bind to a novel complex RA response element in the UCP1 gene promoter (Larose et al. 1996, Rabelo et al. 1996, Bonet et al. 1997).

The present study was undertaken to gain insight into the possible in vivo modulation of BAT thermogenesis by retinoids. Since vitamin A acts as a precursor of RA in animal tissues, we investigated whether BAT thermogenic potential - in terms of expression of the different uncoupling proteins - correlates with vitamin A status and body weight, by comparing mice fed a vitamin A-deficient diet with RA-treated mice.

\section{Materials and Methods}

Animals, diets and $R A$ treatment

NMRI male mice (CRIFFA, Barcelona, Spain) distributed into four experimental groups were used: mice were fed ad libitum with either standard chow (Panlab, Barcelona, Spain) or a vitamin A-deficient diet (ICN, Barcelona, Spain), and treated with either vehicle (olive oil) or all-trans RA (tRA; Sigma, Madrid, Spain). The animals were acclimated to $22^{\circ} \mathrm{C}$, with a 12-h light:12-h darkness cycle; in some experiments, they were transferred to thermoneutrality $\left(28^{\circ} \mathrm{C}\right) 1$ week before initiating the 
Table 1 Effect of vitamin A-deficient diet feeding and tRA treatment on body weight

\begin{tabular}{|c|c|c|c|c|c|c|c|}
\hline & \multirow{2}{*}{\multicolumn{2}{|c|}{ Body weight before treatment $(\mathrm{g})$}} & \multicolumn{4}{|c|}{ Body weight after treatment $(\mathrm{g})$} & \multirow{3}{*}{$\begin{array}{l}\text { Two-way } \\
\text { ANOVA }\end{array}$} \\
\hline & & & \multicolumn{2}{|c|}{ Standard diet } & \multicolumn{2}{|c|}{ Deficient diet } & \\
\hline & Standard diet & Deficient diet & No tRA & tRA & No tRA & tRA & \\
\hline \multicolumn{8}{|l|}{ Experiment } \\
\hline 1 & $\begin{array}{c}39 \cdot 3 \pm 0 \cdot 8 \\
\quad(12)\end{array}$ & $\begin{array}{c}41 \cdot 3 \pm 0 \cdot 8 \\
\quad(12)\end{array}$ & $\begin{array}{c}39 \cdot 7 \pm 1 \cdot 1 \\
(6)\end{array}$ & $\begin{array}{c}36 \cdot 1 \pm 1 \cdot 7 \\
(6)\end{array}$ & $\begin{array}{c}42 \cdot 7 \pm 1 \cdot 2 \\
(6)\end{array}$ & $\begin{array}{c}36 \cdot 3 \pm 0 \cdot 7^{*} \\
(6)\end{array}$ & $\mathrm{T}$ \\
\hline 2 & $\begin{array}{c}39 \cdot 6 \pm 0 \cdot 6 \\
(15)\end{array}$ & $\begin{array}{c}41 \cdot 0 \pm 0 \cdot 6 \\
(14)\end{array}$ & $\begin{array}{c}39 \cdot 6 \pm 0 \cdot 5 \\
(9)\end{array}$ & $\begin{array}{c}36 \cdot 7 \pm 0 \cdot 7^{*} \\
(6)\end{array}$ & $\begin{array}{c}40 \cdot 4 \pm 1 \cdot 0 \\
(7)\end{array}$ & $\begin{array}{c}37 \cdot 0 \pm 0 \cdot 9^{*} \\
(7)\end{array}$ & $\mathrm{T}$ \\
\hline 3 & $\begin{array}{c}43 \cdot 2 \pm 0 \cdot 7 \\
(12)\end{array}$ & $\begin{array}{c}45 \cdot 2 \pm 1 \cdot 0 \\
(12)\end{array}$ & $\begin{array}{c}43 \cdot 9 \pm 1 \cdot 3 \\
(6)\end{array}$ & $\begin{array}{c}40 \cdot 0 \pm 1 \cdot 0^{*} \\
(6)\end{array}$ & $\begin{array}{c}45 \cdot 6 \pm 1 \cdot 0 \\
(6)\end{array}$ & $\begin{array}{c}40 \cdot 9 \pm 2 \cdot 0 \\
(6)\end{array}$ & $\mathrm{T}$ \\
\hline 4 & $\begin{array}{c}43 \cdot 0 \pm 0 \cdot 8 \\
(8)\end{array}$ & $\begin{array}{c}44 \cdot 4 \pm 1 \cdot 8 \\
(12)\end{array}$ & $\begin{array}{c}42 \cdot 1 \pm 1 \cdot 1 \\
(4)\end{array}$ & $\begin{array}{c}36 \cdot 2 \pm 1 \cdot 2^{*} \\
\text { (4) }\end{array}$ & $\begin{array}{c}43 \cdot 7 \pm 2 \cdot 5 \\
(6)\end{array}$ & $\begin{array}{c}37 \cdot 5 \pm 2 \cdot 0 \\
(6)\end{array}$ & $\mathrm{T}$ \\
\hline $1-4$ & $\begin{array}{c}41 \cdot 0 \pm 0 \cdot 4 \\
(47)\end{array}$ & $\begin{array}{c}42 \cdot 9 \pm 0 \cdot 6 \dagger \\
(50)\end{array}$ & $\begin{array}{c}41 \cdot 0 \pm 0 \cdot 6 \\
(25)\end{array}$ & $\begin{array}{c}37 \cdot 3 \pm 0 \cdot 7^{*} \\
(22)\end{array}$ & $\begin{array}{c}43 \cdot 0 \pm 0 \cdot 8 \\
(25)\end{array}$ & $\begin{array}{c}37 \cdot 9 \pm 0 \cdot 8^{*} \\
(25)\end{array}$ & $\mathrm{T}$ \\
\hline
\end{tabular}

The vitamin A-deficient diet was given from day 28 of age, and the animals were killed on day 95 ; vehicle or tRA (100 mg/kg) was subcutaneously injected daily during the 4 days preceding death. Values are means \pm S.E.M. of the number of mice shown in parentheses. One-way ANOVA $(P<0 \cdot 05):{ }^{*}$ tRA versus vehicle, tdeficient diet versus standard diet. Two-way ANOVA $(P<0 \cdot 01)$ : T, effect of tRA treatment.

treatment and until the end of the experiment. The vitamin A-deficient diet was given from day 28 of age, and the animals were killed on day 95 ; tRA $(100 \mathrm{mg} / \mathrm{kg})$ or vehicle was subcutaneously injected once a day during the 4 days immediately before they were killed. Energy intake was determined once a week throughout the period studied, from the actual amount of food consumed by the animals and its caloric equivalence.

\section{Tissue collection}

The animals were killed with $\mathrm{CO}_{2}$, followed by cervical dislocation. The interscapular BAT (IBAT) was excised in its entirety and weighed. A small piece was frozen in liquid $\mathrm{N}_{2}$ and stored at $-70{ }^{\circ} \mathrm{C}$ for RNA extraction. The rest was homogenized in Hepes/sucrose buffer $(250 \mathrm{mM}$ sucrose $/ 1 \mathrm{mM}$ Hepes $/ 0 \cdot 2 \mathrm{mM}$ EDTA buffer, $\mathrm{pH} 7 \cdot 0$ ) in a Teflon/glass homogenizer (ten strokes). After filtering it through a layer of gauze, the homogenate was used to determine the total protein content by the method of Bradford (1976), and the UCP1 levels by immunoblotting, using polyclonal rabbit antiserum raised against purified rat UCP1 and according to Bonet et al. (1997). Specificity of the antiserum for UCP1 was confirmed by immunoblotting of homogenates of BAT and non-BAT tissues, together with purified UCP1 (Puigserver et al. 1991).

\section{RNA extraction and Northern blot analysis}

Reagents and probes used were from Boehringer Mannheim (Barcelona, Spain). Total IBAT RNA was isolated using Tripure reagent; $20 \mu \mathrm{g}$ was fractionated by agarose gel electrophoresis (Jacobsson et al. 1985), transferred onto a nylon membrane by capillary blotting in $20 \times \operatorname{SSC}(1 \times$ SSC is $150 \mathrm{mM} \mathrm{NaCl}, 15 \mathrm{mM}$ trisodium citrate, pH 7•0) (Jacobsson et al. 1985), and fixed with u.v. light.

The RNAs of interest were analyzed by a chemiluminiscence-based procedure, using antisense oligonucleotide probes end-labeled with digoxigenin; the following probes were used: for UCP2 mRNA, 5'-GGC AGAGTTCATGTATCTCGTCTTGACCAC-3' (Roca et al. 1999); for UCP1 mRNA, 5'-GTTGGTTTTAT TCGTGGTCTCCCAGCATAG-3' (Roca et al. 1999); for UCP3 mRNA, 5'-GACTCCTTCTTCCCTGGCG ATGGTTCTGTAGG-3'; for leptin mRNA, 5'-GGT CTGAGGCAGGGAGCAGCTCTTGGAGAAGGC-3'

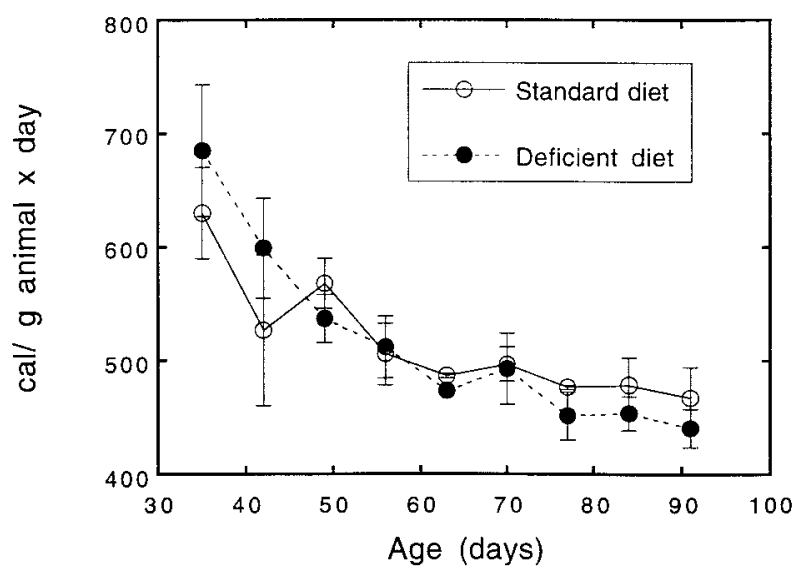

Figure 1 Energy intake curves of NMRI male mice fed standard chow or vitamin A-deficient diet. The data represent the means \pm S.E.M. of data from two independent experiments (six animals per group in each experiment). The vitamin A-deficient diet was given from day 28 of age. Energy intake was determined once a week, from the actual amount of food consumed and its caloric (cal) equivalence. 
Table 2 Effect of vitamin A-deficient diet feeding and tRA treatment on IBAT parameters

\begin{tabular}{|c|c|c|c|c|c|}
\hline & \multicolumn{2}{|c|}{ Standard diet } & \multicolumn{2}{|c|}{ Deficient diet } & \multirow{2}{*}{$\begin{array}{l}\text { Two-way } \\
\text { ANOVA }\end{array}$} \\
\hline & No tRA & tRA & No tRA & $\mathrm{tRA}$ & \\
\hline \multicolumn{6}{|l|}{ Parameter } \\
\hline $\begin{array}{l}\text { IBAT mass } \\
(\mathrm{mg})\end{array}$ & $129 \pm 11$ & $83 \pm 7^{*}$ & $186 \pm 28$ & $124 \pm 17 \dagger$ & $\mathrm{T}, \mathrm{D}$ \\
\hline $\begin{array}{l}\text { Total protein } \\
(\mathrm{mg} / \mathrm{g} \text { IBAT })\end{array}$ & $65 \cdot 7 \pm 6 \cdot 7$ & $82 \cdot 8 \pm 8 \cdot 6$ & $50 \cdot 5 \pm 6 \cdot 2$ & $54 \cdot 8 \pm 6 \cdot 5 \dagger$ & $\mathrm{D}$ \\
\hline $\begin{array}{l}\text { UCP1 protein levels } \\
\text { (arbitrary units/mg IBAT protein) }\end{array}$ & $100 \pm 18$ & $180 \pm 24^{*}$ & $52 \pm 17$ & $104 \pm 16^{*} \dagger$ & $\mathrm{T}, \mathrm{D}$ \\
\hline 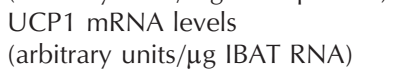 & $100 \pm 12$ & $143 \pm 7^{*}$ & $70 \pm 10$ & $158 \pm 7^{\star}$ & $\mathrm{T}, \mathrm{T} \times \mathrm{D}$ \\
\hline 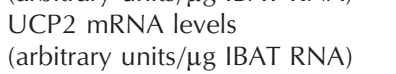 & $100 \pm 24$ & $180 \pm 23^{*}$ & $41 \pm 17$ & $172 \pm 32^{*}$ & $\mathrm{~T}$ \\
\hline 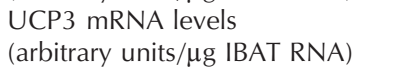 & $100 \pm 11$ & $118 \pm 22$ & $120 \pm 29$ & $94 \pm 25$ & \\
\hline 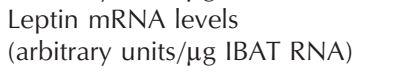 & $100 \pm 29$ & $4 \cdot 4 \pm 1 \cdot 5^{*}$ & $170 \pm 36$ & $7 \cdot 6 \pm 4 \cdot 5^{*}$ & $\mathrm{~T}$ \\
\hline
\end{tabular}

The vitamin A-deficient diet was given from day 28 of age, and the animals were killed on day 95; vehicle or tRA (100 mg/kg) was subcutaneously injected daily during the 4 days preceding death.

Data are the means \pm S.E.M. of at least five animals per group. IBAT mass, total protein, UCP1 protein and leptin mRNA data are means \pm S.E.M. of eight to ten animals per group, distributed in two independent experiments.

UCP1 protein and mRNAs data are expressed relative to the mean value of vehicle-injected standard diet-fed animals, which was set at 100 . Ratios of each mRNA to $18 \mathrm{~S}$ rRNA were calculated to correct for RNA quantity.

One-way ANOVA $(P<0 \cdot 05)$ : *tRA versus vehicle, tdeficient diet versus standard diet. Two-way ANOVA ( $P<0 \cdot 05)$ : T, effect of tRA treatment; D, effect of diet; $\mathrm{T} \times \mathrm{D}$, interaction of treatment and diet.

(Trayhurn et al. 1995) and for 18S rRNA, 5'-CGCCTG CTGCCTTCCTTGGATGTGGTAGCCG-3' (Trayhurn et al. 1995).

Fixed membranes were pre-hybridized at $42{ }^{\circ} \mathrm{C}$ for $15 \mathrm{~min}$ in DIG-Easy Hyb, and then hybridized with the corresponding oligonucleotide probe $(34 \mathrm{ng} / \mathrm{ml}$, except the $18 \mathrm{~S}$ rRNA probe, which was used at $70 \mathrm{pg} / \mathrm{ml}$ ) in DIG-Easy $\mathrm{Hyb}$ at $42{ }^{\circ} \mathrm{C}$ overnight and submitted to $2 \times 15 \mathrm{~min}$ washes in a solution of $2 \times \mathrm{SSC} / 0 \cdot 1 \%(\mathrm{w} / \mathrm{v})$ SDS at room temperature, followed by $2 \times 15 \mathrm{~min}$ washes in $0 \cdot 1 \times \mathrm{SSC} / 0 \cdot 1 \%(\mathrm{w} / \mathrm{v}) \mathrm{SDS}$ at $48{ }^{\circ} \mathrm{C}$. After blocking, the membranes were incubated with an anti-digoxigeninalkaline phosphatase conjugate, then with the chemiluminescent substrate CDP-Star and, finally, exposed to Hyperfilm ECL (Amersham International plc, Amersham, Bucks, UK). Bands in films were analyzed by scanner photodensitometry and quantified using the Biolmage program (Millipore, Bedford, MA, USA). The RNAs of interest were analyzed sequentially on the same membrane, after stripping with boiling $0 \cdot 1 \%(\mathrm{w} / \mathrm{v})$ SDS.

\section{Structural studies}

Animals were transcardially perfused with $4 \%$ paraformaldehyde in $0 \cdot 1 \mathrm{M}$ phosphate buffer, $\mathrm{pH} 7 \cdot 4$, and the IBAT depot was dissected under a surgical microscope and further fixed by immersion in the same fixative for $4 \mathrm{~h}$. The tissue was then dehydrated and embedded in paraffin blocks. Thin sections obtained with a microtome were stained with hematoxylin-eosin and examined by light microscopy.

\section{Results}

Animals fed the vitamin A-deficient diet tend to develop excess body weight

Animals fed the vitamin A-deficient diet for 9 weeks (starting on week 4 of age) had a 3-5\% higher body weight than their littermates fed standard chow. The excess of body weight achieved was modest, but consistent, as shown in Table 1 where the results of four independent experiments are presented. Its significance was increased by the fact that it developed despite energy intake which was essentially the same in the two groups throughout the period studied (Fig. 1). Treatment with tRA triggered a significant reduction of body weight, independent of the diet (Table 1), in accordance with previous results from our group (Puigserver et al. 1996).

Animals fed the vitamin A-deficient diet tend to develop a fatty hypertrophied IBAT with a reduced thermogenic capacity

In response to vitamin A-deficient diet feeding, IBAT mass increased while the amount of protein per gram of tissue decreased (Table 2). The latter result suggested that 

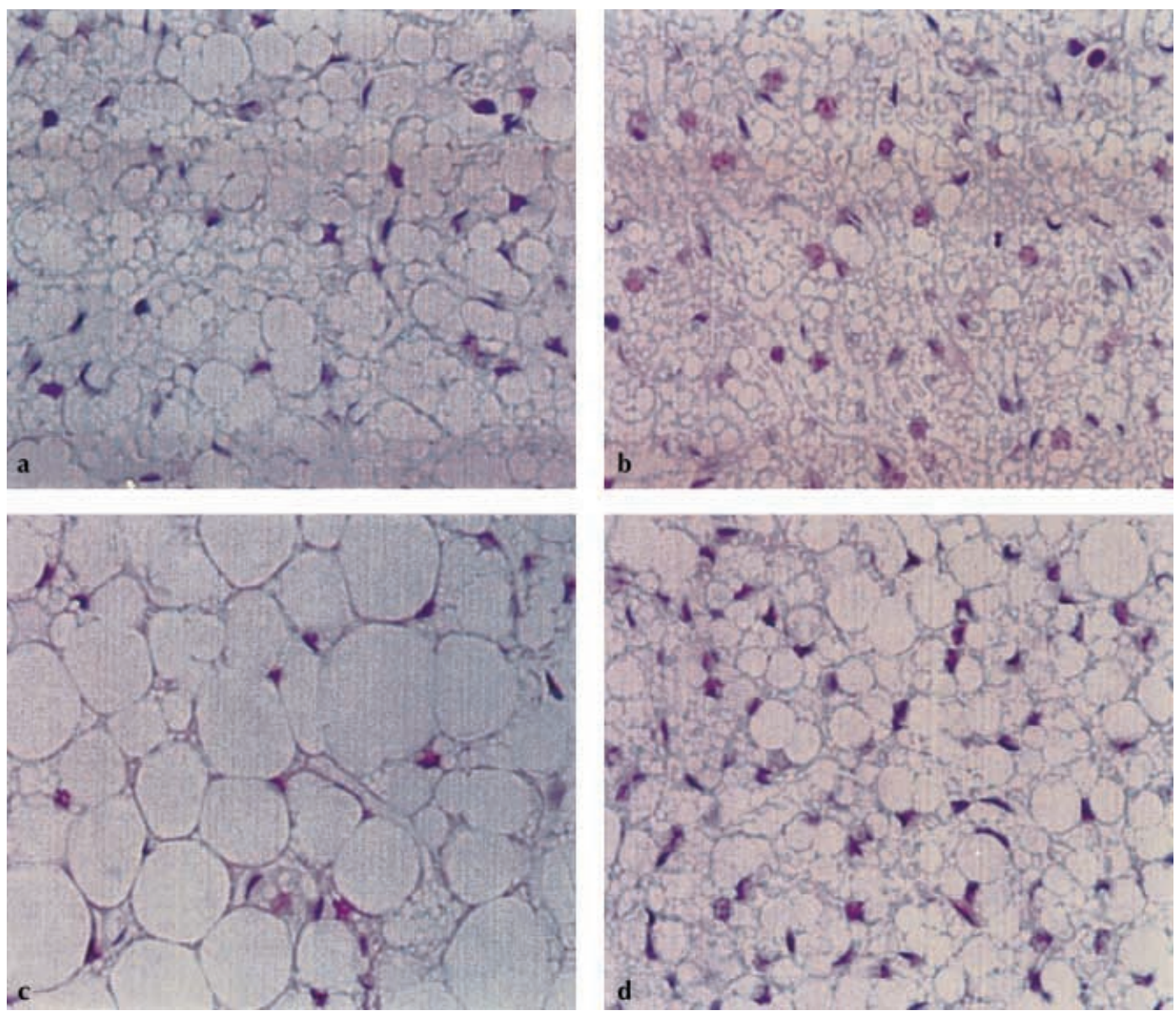

Figure 2 Light microscopy study of IBAT from mice fed standard chow $(a, b)$ or a vitamin A-deficient diet $(c, d)$ and treated $(b, d)$ or not $(a, c)$ with tRA. Fixed sections were stained with hematoxylin-eosin. The vitamin A-deficient diet was given for a period of 9 weeks, starting at week 4 of age; tRA (100 mg/kg) or vehicle was subcutaneously injected daily during the 4 days before the animals were killed. Magnification: $\times 430$.

increased adiposity - rather than increased cellularity accounted for IBAT hypertrophy of vitamin A-deficient diet-fed animals, a suggestion that was corroborated by morphological tissue examination showing that the IBAT adipocytes of these animals were larger in size and more filled with fat than those of the food control animals (Fig. 2). Treatment with tRA, on the other hand, led to a reduction of both the size of the IBAT depot and of IBAT adiposity, in accordance with previous results (Puigserver et al. 1996) and independent of the diet. Reduction of IBAT adiposity was indicated by the trend of IBAT specific protein content to increase after tRA treatment (Table 2), and was clearly confirmed by the results of morphological tissue examination (Fig. 2). Parallel morphology studies also revealed reduction of white fat adiposity after tRA treatment (not shown).

We found similar changes in UCP1 protein, UCP1 mRNA and UCP2 mRNA levels in IBAT in response to the vitamin A content of the diet and tRA treatment: the three parameters tended to be lower in the animals fed the vitamin A-deficient diet than in the food control animals, and the three increased significantly after tRA treatment, independent of the diet (Table 2 and Fig. 3). Levels of UCP3 mRNA in IBAT, on the other hand, were unaffected by the vitamin A content of the diet or tRA treatment (Table 2).

Vitamin A-deficient diet feeding and $t R A$ treatment have opposite effects on leptin $m R N A$ expression in IBAT

Levels of leptin mRNA in IBAT tended to be higher in the animals fed the vitamin A-deficient diet than in the food control animals, and were significantly reduced after tRA treatment independently of the diet (Table 2 and Fig. 3). 


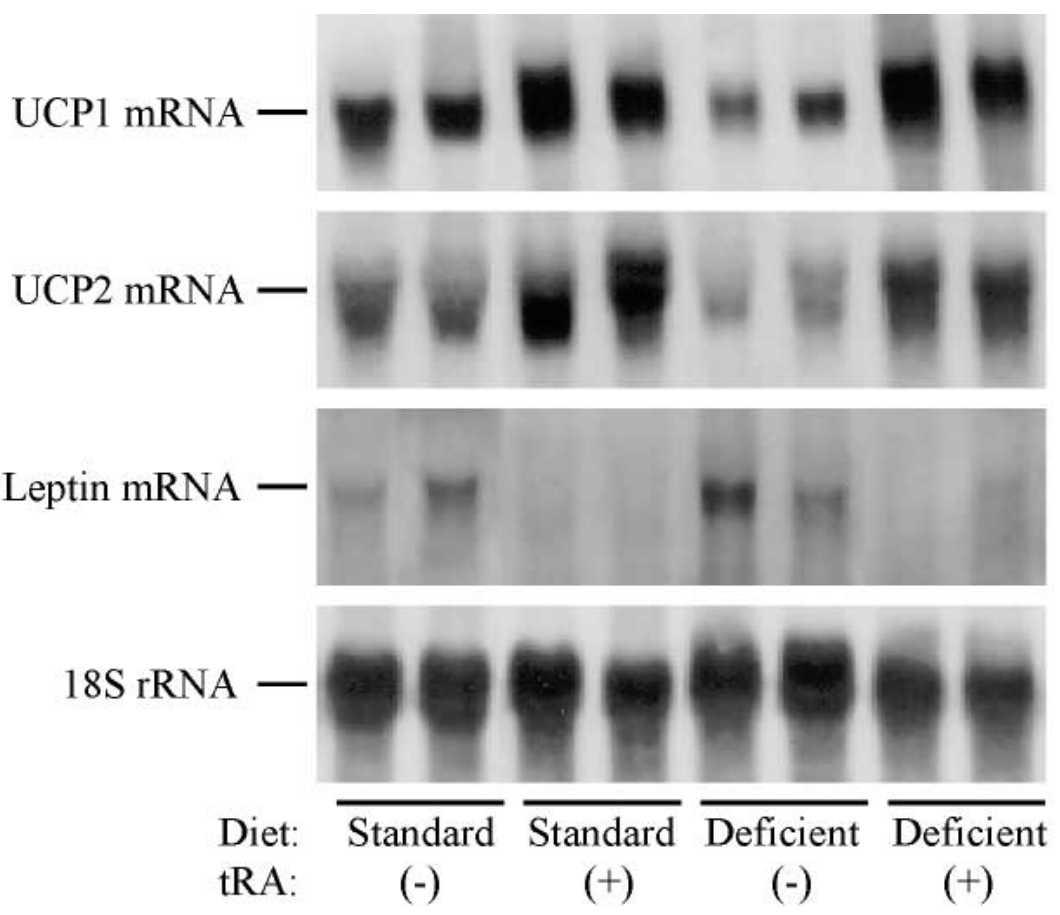

Figure 3 Effect of vitamin A-deficient diet feeding and tRA treatment on the levels of expression of UCP1, UCP2 and leptin mRNA in IBAT. Fifteen micrograms of total IBAT RNA were loaded per lane. The membranes were probed first for UCP2 mRNA and thereafter sequentially stripped and re-probed for the other mRNAs; $18 \mathrm{~S}$ rRNA was the last species analyzed, as a control for quantity of RNA.

\section{Discussion}

The main finding of this work was that chronic feeding of mice with a vitamin A-deficient diet tends to trigger opposite effects to those of tRA treatment, namely an increase of body weight, IBAT weight and IBAT adiposity, and a reduction of IBAT thermogenic capacity in terms not only of UCP1, but also of UCP2 expression. To our knowledge, this is the first evidence that retinoids can activate UCP2 expression in vivo. Our results show the existence of a linkage between the vitamin A status of rodents and their IBAT thermogenic potential, thus supporting the importance of retinoids as physiological regulators of BAT in vivo. This role of retinoids has possibly been ignored because BAT contains sufficient quantities of RA and standard animal diets contain sufficient vitamin A.

We have previously reported that treatment of intact mice with tRA increases UCP1 protein expression in IBAT (Puigserver et al. 1996). Here, we report a parallel tRA-induced increase of UCP2 mRNA expression and show that both UCP1 mRNA and UCP2 mRNA levels tend to be down-regulated in the IBAT of animals fed a vitamin A-deficient diet chronically. Our results therefore point to a similar in vivo regulation of UCP1 and UCP2 (but not UCP3) by tRA. These results contrast with those of Scarpace et al. (2000) who, while this work was in progess, reported a differential response to tRA treatment of UCP1 (which was up-regulated) and UCP2 and UCP3 (which were both down-regulated to approximately 50\% of the control level) in BAT of rats. The reason for the discrepancy is unknown, but differences in drug dosage between the two series of experiments should be considered. Scarpace et al. (2000) killed their rats $5 \mathrm{~h}$ after injection of a single dose of $7.5 \mathrm{mg} / \mathrm{g}$ tRA, while our mice received four doses of $100 \mathrm{mg} / \mathrm{kg}$ tRA, $24 \mathrm{~h}$ apart, and were killed $24 \mathrm{~h}$ after the last dose. A possible explanation could be that there is a temporal regulation of rodent BAT UCP2 mRNA expression by tRA, an immediate decrease followed by a progressive increase when the stimuli (tRA) persists. Further experiments are needed to test this hypothesis. In any case, our results display internal coherence, since a putative sustained lack of RA (in animals chronically fed the vitamin A-deficient diet) was associated with a trend to decreased levels of UCP2 mRNA in BAT. In addition, the tRA-induced increase of BAT UCP2 mRNA expression may be in agreement with a report showing that 9-cis-RA behaves as a transcriptional activator of UCP2 in brown adipocytes differentiated in culture (Carmona et al. 1998), since 
in vivo isomerization of the two RA isomers has been described (Kojima et al. 1994). The mechanism for tRA modulation of the UCP2 gene is unknown; it could rely on the presence of RA response elements in the UCP2 gene promoter, as has been demonstrated for UCP1 (Larose et al. 1996, Rabelo et al. 1996), or it could be a more indirect effect, or it could be both.

The modulation of UCP1 and UCP2 mRNA expression in vitamin A-deficient diet-fed and tRA-treated animals that we found cannot be taken per se as an indication that the thermogenic activity of the animals is affected. However, our finding of a correlation between the observed changes in BAT thermogenic potential and changes in body weight that cannot be explained on the basis of differences in energy intake, nor in apparent physical activity, suggests that this may well be the case. Interestingly, a recent report showed that RA, besides promoting UCP1 gene transcription, strongly increases the proton transport activity of UCP1 in isolated BAT mitochondria and of UCP1 and UCP2 in yeast expression systems (Rial et al. 1999); should this effect take place in whole animals, RA would enhance thermogenesis in the short term, independently of its effects on the expression of the uncoupling proteins. Finally, it must be noted that, in addition to BAT function, other factors could also contribute to the reported effects of RA on body weight.

We found inhibition of leptin mRNA expression in the IBAT of tRA-treated mice, whether fed standard chow or vitamin A-deficient diet; the same effect was reported in the perirenal white fat of vitamin A-sufficient rats acutely treated with RA (Kumar \& Scarpace 1998) or chronically fed a retinol-supplemented diet (Kumar et al. 1999). Considering the marked reduction of IBAT adiposity brought about by tRA treatment (Fig. 2), our results agree with a general positive correlation between leptin expression and cellular adiposity (Friedman \& Halaas 1998). The trend of leptin mRNA expression to be higher in the more fatty IBAT of animals fed the vitamin A-deficient diet is also in agreement with this idea. There are many indications that leptin increases energy expenditure through mechanisms that include induction of the expression of uncoupling proteins (Gong et al. 1997, Scarpace et al. 1997, 1998, Zhou et al. 1997, Cusin et al. 1998, Commins et al. 1999, Rouru et al. 1999). In this context, positive regulation of UCP1 and UCP2 and negative regulation of leptin expression in IBAT after tRA treatment could be viewed as part of a negative-feedback loop that contributes to the regulation of energy homeostasis.

\section{Acknowledgements}

This work was supported by the Spanish Government (grants PB-94-1178 and PM97-0094) and by the European Commission (Contract No. ERBCHRXC) CT940490 and COST Action 918).

\section{References}

Álvarez R, De Andrés J, Yubero P, Viñas O, Mampel T, Iglesias R, Giralt M \& Villarroya F 1995 A novel regulatory pathway of brown fat thermogenesis. Retinoic acid is a transcriptional activator of the mitochondrial uncoupling protein gene. Journal of Biological Chemistry 270 5666-5673.

Bonet ML, Puigserver P, Serra F, Ribot J, Vázquez F, Picó C \& Palou A 1997 Retinoic acid modulates retinoid X receptor alpha and retinoic acid receptor alpha levels of cultured brown adipocytes. FEBS Letters 406 196-200.

Boss O, Samec S, Paolini-Giacobino A, Rossier C, Dulloo A, Seydoux J, Muzzin P \& Giacobino JP 1997 Uncoupling protein-3: a new member of the mitochondrial carrier family with tissuespecific expression. FEBS Letters 408 39-42.

Bradford MM 1976 A rapid and sensitive method for the quantitation of microgram quantities of protein utilizing the principle of proteindye binding. Analytical Biochemistry 72 248-254.

Cannon B, Jacobsson A, Rehnmark S \& Nedergaard J 1996 Signal transduction in brown adipose tissue recruitment: noradrenaline and beyond. International Journal of Obesity 20 S36-S42.

Carmona MC, Valmaseda A, Iglesias R, Mampel T, Viñas O, Giralt M \& Villarroya F 1998 9-cis retinoic acid induces the expression of the uncoupling protein-2 gene in brown adipocytes. FEBS Letters 441 447-450.

Cassard-Doulcier AM, Larose M, Matamala JC, Champigny O, Bouillaud F \& Ricquier D 1994 In vitro interactions between nuclear proteins and uncoupling protein gene promoter reveal several putative transactivating factors including Ets1, retinoic X receptor, thyroid hormone receptor, and a CACCC box-binding protein. Journal of Biological Chemistry 269 24335-24342.

Commins SP, Watson PM, Padgett MA, Dudley A, Argyropoulus G \& Gettys TW 1999 Induction of uncoupling protein expression in brown and white adipose tissue by leptin. Endocrinology 140 292-300.

Cusin I, Zakrzewska KE, Boss O, Muzzin P, Giacobino JP, Ricquier D, Jeanrenau B \& Roher-Jeanrenaud F 1998 Chronic central leptin infusion enhances insulin-stimulated glucose metabolism and favors the expression of uncoupling proteins. Diabetes 47 1014-1019.

Fleury C, Neverova M, Collins S, Raimbault S, Champigny O, Levi-Meyrueis C, Bouillaud F, Seldin MF, Surwit RS, Ricquier D \& Warden CH 1997 Uncoupling protein-2: a novel gene linked to obesity and hyperinsulinemia. Nature Genetics 15 269-272.

Friedman JM \& Halaas JL 1998 Leptin and the regulation of body weight in mammals. Nature $395763-770$.

Gimeno RE, Dembski M, Weng X, Deng N, Shyjan AW, Gimeno CJ, Iris F, Ellis SJ, Woolf EA \& Tartaglia LA 1997 Cloning and characterization of an uncoupling protein homolog: a potential molecular mediator of human thermogenesis. Diabetes 46 900-906.

Gong DW, He Y, Karas M \& Reitman M 1997 Uncoupling protein-3 is a mediator of thermogenesis regulated by thyroid hormone, $\beta 3$-adrenergic agonists, and leptin. Journal of Biological Chemistry 272 24129-24132.

Himms-Hagen J 1990 Brown adipose tissue thermogenesis: interdisciplinary studies. FASEB Journal 4 2890-2898.

Jacobsson A, Stadler U, Glotzer MA \& Kozak LP 1985 Mitochondrial uncoupling protein from mouse brown fat. Journal of Biological Chemistry 260 16250-16254.

Kojima R, Fujimori T, Kiyota N, Toriya Y, Fukuda T, Ohashi T, Sato T, Yoshizawa Y, Takeyama K, Mano H, Masushige S \& Kato S 1994 In vivo isomerization of retinoic acids. Rapid isomer exchange and gene expression. Journal of Biological Chemistry 269 32700-32707.

Kumar MV \& Scarpace PJ 1998 Differential effects of retinoic acid on uncoupling protein-1 and leptin gene expression. Journal of Endocrinology 157 237-243. 
Kumar MV, Sunvold GD \& Scarpace PJ 1999 Dietary vitamin A supplementation in rats: suppression of leptin and induction of UCP1 mRNA. Journal of Lipid Research 40 824-829.

Larose M, Cassard-Doulcier AM, Fleury C, Serra F, Champigny O, Bouillaud F \& Ricquier D 1996 Essential cis-acting elements in rat uncoupling protein gene are in an enhancer containing a complex retinoic acid response domain. Journal of Biological Chemistry 271 31533-31542.

Palou A, Picó C, Bonet ML \& Oliver P 1998 Molecules in focus: the uncoupling protein thermogenin. International Journal of Biochemistry and Cell Biology 30 7-11.

Puigserver P, Lladó I, Palou A \& Gianotti M 1991 Evidence for masking of brown adipose tissue mitochondrial GDP-binding sites in response to fasting in rats made obese by dietary manipulation. Biochemical Journal 279 575-579.

Puigserver P, Vázquez F, Bonet ML, Picó C \& Palou A 1996 In vitro and in vivo induction of the brown adipocyte uncoupling protein thermogenin by retinoic acid. Biochemical Journal 317 827-833.

Rabelo R, Reyes C, Schifman A \& Silva E 1996 A complex retinoic acid response element in the uncoupling protein gene defines a novel role for retinoids in thermogenesis. Endocrinology 137 3488-3496.

Rial E, Gonzalez-Barroso M, Fleury C, Iturrizaga S, Sanchis D, Jimenez-Jimenez J, Ricquier D, Goubern M \& Bouillaud F 1999 Retinoids activate proton transport by the uncoupling proteins UCP1 and UCP2. EMBO Journal 18 5827-5833.

Roca P, Rodriguez AM, Oliver P, Bonet ML, Quevedo S, Picó C \& Palou A 1999 Brown adipose tissue response to cafeteria dietfeeding involves induction of the UCP2 gene and is impaired in female rats compared with males. Pflügers Archiv: European Journal of Physiology 438 628-634.

Rouru J, Cusin I, Zakrzewska KE, Jeanrenaud B \& RohnerJeanrenaud F 1999 Effects of intravenously infused leptin on insulin sensitivity and on the expression of uncoupling proteins in brown adipose tisssue. Endocrinology 140 3688-3692.

Scarpace PJ, Matheny M, Pollock BH \& Tymer N 1997 Leptin increases uncoupling protein expression and energy expenditure. American Journal of Physiology 273 e226-e230.

Scarpace PJ, Nicolson M \& Matheny M 1998 UCP2, UCP3 and leptin gene expression: modulation by food restriction and leptin. Journal of Endocrinology 159 349-357.

Scarpace PJ, Matheny M, Moore RL \& Kumar MV 2000 Modulation of uncoupling protein 2 and uncoupling protein 3: regulation by denervation, leptin and retinoic acid treatment. Journal of Endocrinology 164 331-337.

Susulic VS \& Lowell BB 1995 Brown adipose tissue and the regulation of body fat stores. Current opinion in Endocrinology and Diabetes 3 44-50.

Trayhurn P, Duncan JS \& Rayner V 1995 Acute cold-induced supression of $o b$ (obese) gene expression in white adipose tissue of mice: mediation by the sympathetic system. Biochemical Journal 311 729-733.

Vidal-Puig A, Solanes G, Grujic D, Flier JS \& Lowell BB 1997 UCP3: an uncoupling protein homologue expressed preferentially and abundantly in skeletal muscle and adipose tissue. Biochemical and Biophysical Research Communications 235 79-82.

Zhou YT, Shimabukuro M, Koyama K, Lee Y, Wang MY, Trieu F, Newgard CB \& Unger RH 1997 Induction by leptin of uncoupling protein-2 and enzymes of fatty acid oxidation. PNAS 94 6386-6390.

Received 18 February 2000

Accepted 26 April 2000 